\title{
Political Realism as Methods not Metaethics
}

\author{
Jonathan Leader Maynard ${ }^{1}$
}

Accepted: 31 March 2021 /Published online: 13 April 2021

(C) The Author(s) 2021

\begin{abstract}
This paper makes the case for a revision of contemporary forms of political realism in political theory. I argue that contemporary realists have gone awry in increasingly centring their approach around a metaethical claim: that political theory should be rooted in a political form of normativity that is distinct from moral normativity. Several critics of realism have argued that this claim is unconvincing. But I suggest that it is also a counterintuitive starting point for realism, and one unnecessary to avoid the 'applied morality' approach to political theory that realists oppose. Instead, realism should be methodologically orientated around what I term 'empirically constitutive political realities' - enduring features of real political contexts that are systematically consequential in their normative implications. Realists can persuasively argue that such empirically constitutive political realities must be attended to in political theory-building, and not merely treated as a context in which independently formulated moral theories are simply applied. This framing of realism accords real politics a genuinely foundational theoretical role, but without requiring any contentious metaethical stance about a non-moral political normativity. I explain some methodological implications that follow for realism - in particular the need to prioritise empirically grounded theorisation of real political contexts over abstract and rather essentialist claims about 'the political'. I also argue that such a framing of realism helps engender a more accurate, less divisive, and more pluralist conception of methodological debates within political theory.
\end{abstract}

Keywords Political realism $\cdot$ Methodology $\cdot$ Normativity $\cdot$ Metaethics $\cdot$ Political theory

\section{Introduction}

In what sense should our thinking about politics be realistic? Within political theory, recent debates over realism have come to revolve around the respective role of morality and politics in normative theorising. 'Political realists' have attacked an understanding of political theory

Jonathan Leader Maynard

jonathan.leader_maynard@kcl.ac.uk

1 King's College London, London, UK 
as a kind of 'applied morality,' which starts from moral principles that are then used to address normative questions about politics. Instead, realists argue, political theory should 'start' with reflection on the distinctive character of real politics, and the concerns and considerations it generates.

In this paper, I propose a revision to the way much recent realist scholarship has advanced this argument. Realists are right to challenge a vision of political theory as applied morality. But I argue that they have gone awry in increasingly centring this challenge around what is fundamentally a metaethical ${ }^{1}$ claim: that political theory should be rooted in a political form of normativity that is distinct from moral normativity. ${ }^{2}$ Several critics of realism have contended that this metaethical stance is, on interrogation, unconvincing (Erman and Möller 2015; Estlund 2017; Larmore 2018; Leader Maynard and Worsnip 2018). That 'negative' critique made, this paper suggests that orientating realism around a metaethically distinctive political normativity has always been a counterintuitive and unnecessary direction for political realists to take.

Instead, as realists themselves emphasise, political realism is best construed as a methodological orientation - i.e. a set of processes for generating certain kinds of human understanding and avoiding certain kinds of error (Hall 2017; Jubb 2017, 2019). Realists have nevertheless become embroiled in metaethics because of an overly sweeping suspicion about 'morality.' Realists rightly argue that political realities should not be treated as merely a context of application for independently formulated moral theories. But the fact that particular forms of detached moral argument treat political realities as a mere context of application does not mean that any moral theory must ignore them, nor implies that such political realities have 'their own' non-moral kind of normative force. I contend, in other words, that realists have been too hung up on the metaethical notion of 'morality' - which most philosophers use extremely broadly and fairly banally - rather than the methodological notion of 'application' which is really what is at issue.

I therefore seek to build a bridge between realists and their critics, by arguing that real politics should play a genuinely foundational role in political theory, but not because of any argument about the character of the normativity - the nature of the 'oughts' - that underpin politics. Instead, realists should emphasise that political 'theory-building' is an intellectually generative activity. It is not merely a deductive 'working out' of arguments from self-evident first principles - like the formulation of a mathematical solution - but produces new concepts and frameworks that more or less successfully capture aspects of human experience and thereby profoundly shape our normative conclusions. Consequently, when political realities with systematic normative implications are neglected in theory-building, and largely relegated to theory-application, this distorts the resulting normative conclusions.

I advance this argument in two parts. In part 1, I briefly summarise why the claim that political theory should be rooted in a 'distinctively political normativity' must be read as a metaethical claim, and why the resort to this metaethical claim is peculiar. In part 2, I outline a methodological framing of realism which avoids this claim, orientated around what I term empirically constitutive political realities: enduring features of real politics that are systematically consequential in their normative implications. This framing encourages realists to move

\footnotetext{
${ }^{1}$ It would be more literal to say 'metanormative', but since this is true of various stances traditionally framed as part of metaethics, I retain the standard terminology.

${ }^{2}$ There is much internal variation within realism, and not all realists advance such a claim - see, for example: Mantena (2012); Larmore (2018); Frazer (2018). For a more moderate assertion of political normativity's distinctiveness, see: Sleat (2016).
} 
away from rather abstract and essentialist claims about 'the political,' in favour of a more promising tradition of realist inquiry that encourages innovative and empirically grounded theorisation of real politics.

\section{Political Realism as Metaethics}

Most realists do not contend that morality has no place in political theory. But they often suggest that political theory should primarily be rooted in a distinctively political normativity which is not reducible to moral normativity. This argument can be interpreted in several ways. One intuitive reading is that politics involves distinct normative considerations which are different to other domains of life, especially the domain of private individual conduct. In this sense, the normative theorising appropriate to politics is distinctive: it cannot be reduced to the normative considerations of other (moral) domains. This is not a metaethical stance, but a substantive view about the relevant principles and concepts - the normative content - appropriate for evaluating politics. Realists have certainly implied, on occasion, that this claim is key to their critique of 'moralist' political theory. Rossi and Sleat (2014: 4), for example, explicitly suggest that "political moralism reduces political problems to matters of personal morality," while Philp (2012: 634) defends realism on the grounds that there is "a difference between how private individuals ought to act and how those in politics must act." Jubb (2019: 362) more broadly, characterises realism as claiming that "political normativity [is] distinct from moral normativity, in the sense that the weight, direction and relevance of different considerations would all systematically be altered by politics' constitutive features" (see also: Hall 2017: 284).

The problem with this interpretation of realism, however, is that the vast bulk of 'moralist' political theorists, whom realists take themselves to be critiquing, already fully accept that normative reasoning about politics involves distinctive considerations which go beyond the ethical reasoning appropriate for private individual conduct (Estlund 2017: 387; Leader Maynard and Worsnip 2018: 759-62). Indeed, many domains of human activity - medical treatment, journalism, academic research - are distinctive in this sense: involving features which 'systematically alter' normative theorising. But that doesn't accord each domain its own sui generis kind of normativity, nor imply that the normativity involved is non-moral. Hence, we talk readily of medical ethics, media ethics and research ethics, rather than positing a non-moral 'medical normativity', 'media normativity,' 'research normativity' and so on. Likewise, the fact that politics involves distinctive concerns with, for example, representation, legitimacy and order does not imply that distinctively political normative principles are non-moral in nature.

This illustrates how philosophers do not generally, contra the accusations of some realists, take 'morality' to mean something like 'the ethics of private individual conduct' (see: Gert and Gert 2016). ${ }^{3}$ Nor is such a limitation a feature of lay usage: the relevant Oxford English Dictionary entry for 'morality' is simply, "The branch of knowledge concerned with right and wrong conduct, duty, responsibility, etc." while Merriam-Webster defines 'moral' as simply "of or relating to principles of right and wrong in behavior." Many moralists, moreover, explicitly reject the claim that moral reasoning about politics is limited to extensions of the rules governing private individual conduct (for example: Stemplowska and Swift 2012: 381; Estlund 2017: 387). So any suggestion that

\footnotetext{
${ }^{3}$ The leading realist Bernard Williams does explicitly use a specific conceptualisation of morality which he distinguishes from 'ethics', see: Williams (1985); Owen (2018). But this conceptualisation should not be ascribed to other philosophers who do not employ it.
} 
'moralist' political theory is generally "private morality writ large" is simply a misreading. ${ }^{4}$ Even canonical 'moralists' have evinced deep interest in distinctively political issues (such as legitimacy, collective moral disagreement, historical oppression, or the value of existing cultural and political norms) that make no sense in the context of personal moral conduct (for example: Nagel 1987; Kymlicka 1989; Rawls 1993; Anderson 2010). There is therefore a risk that realists are simply rejecting morality in a much narrower sense than most moralists are employing it. ${ }^{5}$

If the notion of a distinctive political normativity is really to distinguish realists and moralists, then, it must go deeper - but how it would do so remains unclear. ${ }^{6}$ Perhaps realists want to suggest that political and moral normativity are rooted in different substantive sources, reflecting realism's normative appeal to concrete practices and realities rather than abstract values (Rossi and Sleat 2014: 690). But it is always going to be difficult to stably ground realism in the contention that political normativity is rooted in a different source than moral normativity, since the proper source of moral normativity is itself so diversely theorised (see also Estlund 2017). I suspect that this is a source of confusion in the realism-moralism debate, with some realists assuming that moralists see 'morality' as some special 'source' of normativity that is just asserted to regulate politics, much as a religion might claim that their god has authority over individuals' private behaviour. In truth, moralists tend to portray morality as simply a general class of normative claims and considerations (for example, those that possess 'overridingness' and/or affect others) that includes claims and considerations about politics (see, e.g.: Hare 1981: 52-7; Gert and Gert 2016; Estlund 2017).

For present purposes, however, I remain neutral on the exact reading of political normativity's distinctiveness. What matters is that, if not merely the rather uncontroversial claim that politics involves distinctive normative considerations, such a claim is fundamentally metaethical. It is in some sense concerned with the meaning of different kinds of normativity, their sources of normative force, how normative appeals within different categories may be grounded, and so forth. This seems a peculiar starting point for political realism. There is, for a start, something paradoxical about rooting a movement concerned with the detachment of political theory from real politics in a highly abstract philosophical claim about the character of different normativities. Relying on such a metaethical claim is also odd, because most realists clearly have little interest in metaethics as a field (Nye 2015). Despite claiming that political normativity is distinct from moral normativity, realists have engaged in little discussion of the nature of 'normativity', 'morality' or how normativities are distinguished. ${ }^{7}$ In the bibliographies of realist writings, publications in metaethics are almost entirely absent. Realists have displayed some interest in questions of grounding and the facts-principles relationship, but primarily through direct engagement with substantive political

\footnotetext{
${ }^{4}$ Several realists recognise this, e.g. Sabl and Sagar (2017: 272). Again, certain moralists may be exceptions - as Jubb (2019: 362) suggests of G.A. Cohen and revisionist just war theories. But most moralists do not reduce 'morality' to 'private morality,' so this is no implication of moral normativity itself. With respect to Jubb's second example, for instance, it is notable that the most influential opponent of just war revisionism, Michael Walzer, still roots his contrasting approach in moral normativity (see: Walzer 1980).

${ }^{5}$ Some realists may suggest that political normativity is not wholly separate from moral normativity: that morality has its place in politics, but political normativity can't be reduced to it. But this uses the term 'normativity' to merely mean a collection of normative considerations (which could contain both moral and political elements), rather than, as is more typical, to denote a kind of normative consideration (as with the distinction between moral, prudential, aesthetic or instrumental normativity). Realists still seem to need some normative separateness here if 'political considerations' do not themselves depend on 'moral considerations' at some level. My thanks to Matt Sleat for pressing me on this point.

${ }^{6}$ Even Jubb (2019), entitled 'On What a Distinctively Political Normativity Is,' contains no explicit specification.

7 On such questions, see: Korsgaard (1996); Broome (1999, 2013); Gert and Gert (2016); Dorsey (2016); Leader Maynard and Worsnip (2018).
} 
theory rather than metaethical scholarship (Jubb 2009; Hall 2013). I do not primarily intend this as a criticism - my point is that it is indicative of where the intellectual action lies for realists.

Metaethical concerns have been peripheral, moreover, to the broader realist tradition which many contemporary realists see themselves as reviving. Leading proto-realists such as Max Weber, Hans Morgenthau, Hannah Arendt, Isaiah Berlin or Judith Shklar made no efforts to carve out a distinctively political normativity independent from moral normativity, nor denied that their theories depended on moral values. Shklar (1989: 29-30), for example, emphasises that:

\begin{abstract}
"The liberalism of fear... does not, to be sure, offer a summum bonum toward which all political agents should strive, but it certainly does begin with a summum malum, which all of us know and would avoid if only we could. That evil is cruelty and the fear it inspires, and the very fear of fear itself. To that extent the liberalism of fear makes a universal and especially a cosmopolitan claim... Because the fear of systematic cruelty is so universal, moral claims based on its prohibition have an immediate appeal and can gain recognition without much argument... If the prohibition of cruelty can be universalized and recognized as a necessary condition of the dignity of persons, then it can become a principle of political morality" [my emphasis].
\end{abstract}

Realist themes are clear here, but this passage shows how far away Shklar is from contemporary realist demands that political theory should 'begin' with politics rather than morality. Shklar 'begins' with both: with those cruelties or evils which can arise in politics, and the suggestion that opposition to those cruelties can comprise a form of political morality (see also: Forrester 2012: 250).

Similarly, Morgenthau (1948/1993: 12), the great theorist of classical realism in international relations, offered a nuanced account of the place of morality in realist thought, stating explicitly:

\begin{abstract}
"Political realism is aware of the moral significance of political action... Realism maintains that universal moral principles cannot be applied to the actions of states in their abstract universal formulation, but that they must be filtered through the concrete circumstances of time and place... Both individual and state must judge political action by universal moral principles, such as that of liberty. Yet while the individual has a moral right to sacrifice himself in defense of such a moral principle, the state has no right to let its moral disapprobation of the infringement of liberty get in the way of successful political action, itself inspired by the moral principle of national survival" [my emphasis].
\end{abstract}

Even Bernard Williams (2005: 5) answers his own question of "whether the [Basic Legitimation Demand] is a moral principle" with the rather elliptic non-denial that: "If it is, it does not represent a morality which is prior to politics." To the extent that 'morality' frustrated these theorists, they were generally concerned with the problems of certain kinds of detached moral argument or mentality, not with morality as such (see also: Morgenthau 1948/1993: 13; Mantena 2012: 455).

Given all this, it is perhaps unsurprising that contemporary realists do not see detailed metaethical debate as reflecting the fundamental purposes of their approach. Jubb's recent response to Leader Maynard and Worsnip (2018) is illustrative. While briefly commenting on our critique of potential realist arguments for a distinctively political normativity, Jubb's 
central claim is that analysing realism through such analytical critique is "unproductive." Jubb (2019: 361-2) elaborates:

"Realism is most sensibly understood as a hostility to a way of doing political philosophy and theory... The challenge that realism presents to moralism is unlikely to be settled by treating it as an attempt to demonstrate, in analytically rigorous terms, that moralism makes conceptual mistakes. Although such a strategy is problematic partly because it tries to assess realism on moralism's terms, that is presumably inevitable to some degree. Instead, attempting to adjudicate between realism and moralism at the level of precise and perfectly generalizable methodological prescriptions is in the end unsatisfactory because there is not sufficient common ground to agree on the prescriptions at stake..."

At one level, this response seems like something of a theoretical cop-out. The rigour, precision and conceptual clarity of arguments is not the only virtue of political theories, but it is a mark of good scholarship, not some idiosyncratic demand only valued in moralist analytical philosophy. Nevertheless, I take Jubb's underlying sentiment here seriously - namely that something has gone wrong if we treat realism as a detailed analytical critique of moral normativity. But this is precisely the reason to think that realism should not be built on contentious metaethical claims about the relationship between moral and political normativity. Instead, realism should return to its roots: a methodological concern with the way enduring features of real politics should exert foundational influence over our political theorising.

Part of the problem, here, is the excessively dichotomising way in which realists have described political theory as prioritising either morality or politics - as though a reliance on moral normativity implies giving absolute 'priority' to abstract moral reasoning over any consideration of real politics. In reality, political theories are rarely deductive edifices built on purely 'moral' or 'political' bedrocks, as several realists have come to emphasise. As Sleat (2018: 17), for example, observes:

"[I]t has probably not been too helpful that the discussion of the relationship between morality and politics has been cast in terms of their 'autonomy' or the 'priority' of one over the other. The idea of fully autonomous spheres of human life is a deeply implausible one. And it is never quite clear exactly what is meant by saying that morality has priority over politics or vice versa."

Abandoning this dichotomy is the step forwards that I wish to pursue in the rest of this paper, by arguing that politics can be genuinely foundational to normative theorising - avoiding a political theory that is merely 'applied morality' - without denying the moral nature of the normativity involved.

\section{Political Realism as Methods}

Instead of focusing on a distinctively political normativity, I suggest that realism should be framed as a methodological orientation centred around a foundational theoretical attentiveness to what I will call empirically constitutive political realities. By this, I mean features that are a) enduringly characteristic of some specified category of real-world political situations, and b) systematically 
consequential in their normative implications. ${ }^{8}$ There are many categories of real-world political situations we might be interested in here, which could be general or specific. Some realists may be broadly concerned with 'politics in the foreseeable future.' They might point to broad constitutive political realities such as the ideological manipulation of normative arguments, the ineradicability of reasonable and unreasonable disagreement, and so on. Other realist theories could focus on narrower scopes of enquiry, such as 'post-authoritarian transitions in the $21^{\text {st }}$ Century' or 'democracies in an era of globalisation.' They might point to more specific constitutive political realities such as the indeterminacy of conceptions of political community under transitional authorities or porous borders, or the propensity for extreme nationalist radicalisation under weakly institutionalised party competition or high immigration, and so on. ${ }^{9}$

This framing does not, crucially, reduce realism to merely a concern with ad hoc empirical facts. That would still smack too much of 'applied ethics', since such empirical facts might simply be 'plugged into' moral theories which are themselves built independently from any serious consideration of politics. My suggestion is that this contrast between 'plugging in' real politics to a pre-existing (and apolitical) moral theory as part of theory application, and analysing constitutive political realities as part of normative theory-building itself, is what realists should really be understood as getting at. The strongest realist argument for a 'political political theory' is that political conditions have various constitutive features amenable to theorisation (Sleat 2016: 253-4), which systematically alter the content and character of normative theories appropriate to such conditions, and must therefore be attended to as part of theory-building and not merely during theory-application (see, again: Jubb 2019: 362). But there is simply no need to claim that such constitutive political realities possess some innate non-moral normative power, unless one has already decided that morality must, for some reason, exclude such realities - a claim that neither realists nor moralists have defended.

While this framing maintains realism's existing focus on constitutive features of politics, it modifies the conceptualisation of such features and their methodological role. In emphasising empirically constitutive political realities, I seek to disassociate realism from the argument that a non-moral political normativity can be grounded in 'what counts as a political situation', i.e. in the semantically constitutive features of politics. Some realists have been attracted to Williams' (2005: 5) suggestion that a normative principle - the Basic Legitimation Demand (BLD) - can be derived from the very meaning of a political situation, since: "The situation of one lot of people terrorizing another lot of people is not per se a political situation: it is, rather, the situation which the existence of the political is in the first place supposed to alleviate" (see also: Hall 2015; Sleat 2016: 256-7; Sagar 2018). This is not an obvious definition of politics: few who are not already adherents to Williams' argument are going to be comfortable claiming that state terror or genocidal violence are not political. Nevertheless, thick definitions of politics like Williams' are possible. But one cannot generate normative force out of such semantic reshuffling: Williams has simply moved his normative argument for the avoidance of terror into his definition, so that the question "why should we avoid a politics of state terror" has merely been restated as "why should we practice politics (as defined by

\footnotetext{
${ }^{8}$ My conception of empirically constitutive political realities is indebted to understandings of non-semantic constitutive relationships within philosophy of science, see: Ylikoski (2013).

${ }^{9}$ Whether such features actually are enduringly characteristic and systematically consequential is naturally a matter for debate.
} 
Williams) rather than state terror?" (Leader Maynard and Worsnip 2018: 781-5, see also Estlund 2014: 130-1). ${ }^{10}$ Since the definition of politics is up for debate, we need some account of why a particular conception of politics, such as Williams', is normatively valuable. $^{11}$

A more compelling version of this realist argument is ontological rather than semantic. Sleat (2016: 254-60), for example, contends that there are certain essential "general conditions of politics" such as disagreement, authority, and legitimate coercion. "Being constitutive of politics," he argues, "political values must take [such conditions] as fixed features of the political domain...for a value to be a value for politics it must be consistent with their presence" (Sleat 2016: 258). This argument, from my perspective, moves in the right direction: taking us away from semantic stipulations in favour of characterisations of real politics as a human activity (see also: Sleat 2016: 267-8). But I am sceptical of the notion that politics has ontologically fixed (as opposed to empirically enduring) constitutive features, since, as Sleat (2016: 266) acknowledges, politics is a socially constructed practice. This problem becomes much sharper once we acknowledge that the degree and form of disagreement, authority, or legitimate coercion 'required' by the political domain is highly uncertain. So in what way, and how far, must a political theory take such features as "fixed" in order to avoid being ruinously apolitical? My suspicion is that this question - methodologically crucial for generating specific normative implications - cannot be effectively answered at the level of (necessarily) general claims about the constitution of politics as such.

Shifting the focus to empirically constitutive political realities avoids these problems. Instead of anchoring realism in universalising semantic or ontological claims about politics as such, it appropriately places the emphasis back on real politics and actual contexts. Empirically constitutive political realities are not crucial because they are conceptually or ontologically required for something to count as politics. They matter because they are real, enduring and systematically consequential features of certain actual political conditions that concern us. We may be able to imagine political conditions that lack such features, and we may be able to think about ways to ultimately change or eliminate those features. All the realist needs to claim is that a profoundly different kind of political theory would be needed once such profoundly different political conditions obtain. ${ }^{12}$ It is by attending to empirically constitutive political realities in theory-building that we make the nature of our theorising about politics (as opposed to the nature of the normativity it draws on) distinctly political, and not merely an 'application' of an apolitical moral theory built in isolation from such features of real politics. Methodologically, this encourages realists to move away from rather abstract generalisations about 'the political', which will always be highly indeterminate and contestable in their normative implications. It instead foregrounds realism's more empirically grounded

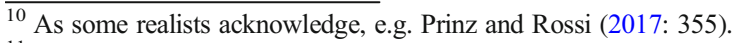

${ }^{11}$ Such arguments are possible - for example, by focusing on Shklar's summum malum of severe cruelty, common to repressive political orders. But repressive orders have always had their champions, and fear of 'cruelty' can underpin the justification of absolute domination of potentially threatening out-groups as well as a 'liberalism of fear.' In this sense, as Larmore (2018: 40-44) argues, any answer to the 'first political question' depends on moral assumptions.

12 This supports realists' suspicions about moral arguments alien to particular political contexts - "Playing Kant at the Court of King Arthur", as Jubb (2015) memorably puts it - or their contention that certain values cannot "be a value for us given facts of the political society of which we are a part" (Sleat 2016: 260). Realists do not need to claim that such alien arguments or values are 'not political' in some universal sense, merely that they are not the kind of political theory that "makes sense" (Williams 2005: 10-11) to the actual political conditions we face (as Sleat 2016: 261-2 explicitly affirms).
} 
theorisation of actual aspects of real politics and its interdisciplinary connections with history, ethnography, and social science (see Paul Sagar's contribution in Zacka et al. 2020).

To illustrate the idea of such empirically constitutive political realities, consider the notion of 'anarchy' in international normative theory. International relations realists have long emphasised the distinctiveness of international politics, on the basis that it is enduringly and systematically shaped by anarchy: the absence of a sovereign authority with the power to enforce binding arrangements. Anarchy is neither simply an empirical fact which can be plugged into political theories formulated for domestic politics, nor part of the definition of what counts as international politics - indeed, the degree to which international politics need be anarchical is open to question. Anarchy matters because it is an enduringly characteristic and systematically consequential feature of real-world international politics, rendering political theories formulated for domestic politics inadequate for the international domain. Central concepts of domestic political theory - such as 'legislators,' 'representation,' 'law,' 'consent,' or 'public and private' - either cannot be applied to international politics or must take on radically different meanings and functions in the international sphere given the different character of human relations under anarchy (although see: Walker 1992). We need a different set of theoretical tools, attuned to a different set of considerations and behavioural dynamics, appropriate to the constitutive political realities of the international domain. This involves no claims that the normativity underlying international politics is not moral, but it does claim that normative theories appropriate to international politics must attend to its foundational character, and cannot be mere 'applications' of the normative theories of other domains.

As further illustration, this portrayal of realism can be applied to existing 'realist methods,' which may be understood as grappling with such empirically constitutive political realities. Many realists have emphasised, for example, the methodological importance of what might be called immanent grounding - as Pettit (2017: 332) puts it: "Political philosophy should begin from the concerns of people in the society for which it prescribes, not from an imported set of ethical principles." This could reflect a deep scepticism about the value of 'ethical' principles in general, but it need not. It would depend on the nature of the ethical theory involved, and Pettit is careful to oppose himself to a particular "sort of moralism" rather than morality per se. What the value of immanent grounding depends on, however, is an argument about the limited potential of politically unsituated rational argument to address actual political disagreements, the character of human motivation in actual political conditions, and the persistent normative centrality of certain real world concerns - such as, for Pettit, the "domination complaint." These are empirically constitutive features of real politics for the foreseeable future - and arguments for immanent grounding are best presented, I suggest, as contending that political theory needs to incorporate such features into theory-building to provide meaningful normative guidance about real politics.

Similarly, realists such as Prinz and Rossi (2017) have advanced ideology critique as a key method of realist political theory, focused on the assessment of normative theories in terms of their actual operative effects in politics. While Prinz and Rossi (2017: 357) suggest that ideology critique may be used to ground something akin to Williams' "Critical Theory Principle" in "epistemic rather than moral considerations", there is no need to see ideology critique as purely epistemically grounded. ${ }^{13} \mathrm{We}$ simply need to appreciate that it is an enduring

\footnotetext{
${ }^{13}$ Indeed, a purely epistemic critique only casts doubt on whether we have justified reasons to believe in normative claims, which is distinct from a critique of the normative content of the claims themselves (which appears to be Williams' intended function of the Critical Theory Principle).
} 
and systematically consequential feature of the political conditions human beings face that principles and theories, however excellent the moral reasoning that underlies their intended form, shape political outcomes through motivated reasoning, strategic legitimation efforts, institutionalisation, and propaganda. Any political assessment of a normative theory should be concerned to assess not just its intellectual attractiveness, but also its likely political impact when operationalised under such conditions.

This argument hangs, of course, on a distinction between theory-building - the formation of key concepts, frameworks and analytical tools for a particular domain of inquiry - and theoryapplication - the use of theory to address specific problems or questions in that domain. A nonrealist sceptic might ask why empirically constitutive political realities need to be theorised at all - why can't they just be plugged into an apolitical moral theory at the stage of application? Why can't the potential ideological manipulation of principles and theories simply be analysed via a bare-bones utilitarianism, for example, itself built without any consideration of such real political dynamics? ${ }^{14}$

My suggestion, here, is that the realist should appeal to an understanding of theorybuilding as profoundly generative of human intellectual capacities, rather than merely a clarificatory or deductive 'working out' of pre-given or self-evident notions. Asking why a bare-bones utilitarianism can't adequately handle ideological manipulations of principles and theories is rather like asking why we can't explain political revolutions purely using theories of neuroscience. As products of human decision making, political revolutions may ultimately be reducible to neurological processes - so perhaps hyperintelligent beings might one day be able to explain all large-scale social phenomena in such terms. But theories of neuroscience are simply not well-suited for human beings trying to explain political revolutions for the foreseeable future. 'Plugging in' all the relevant neurological facts is both practically and cognitively beyond us. Rather than reducing all phenomena to some all-powerful set of master principles, human understanding tends to advance more effectively through more specialist and detailed theory-building, generating new concepts and frameworks that allow us to more effectively and expansively get a handle on particular domains of natural and social reality. ${ }^{15}$ Because theory-building plays such a generative role, neglecting some aspect of reality in theory-building will hamper theory-application if that aspect is an enduring and systematically consequential feature of the phenomena we seek to address.

Similarly, while a unified normative theory that could answer all normative puzzles by applying a small set of master concepts might be conceivable, the realist can plausibly argue that it is unviable for present-day humans (see also: Miller 2008). Moral theories built without consideration of empirically constitutive political realities will struggle to handle various problems and questions - even once lots of empirical facts are 'plugged in' - because they do not offer the underlying theoretical resources needed. Failing to attend to such constitutive political realities in their foundational concepts, arguments, frameworks, and values, they will be impoverished of relevant insights and analytical techniques when applied to answer concrete questions. Greater attention to constitutive political realities in the formulation of our basic concepts and frameworks, by contrast, opens new avenues of understanding, new

\footnotetext{
${ }^{14}$ My thanks to an anonymous reviewer for pressing me on this point.

${ }^{15}$ This has some affinity with arguments about 'middle-range' theories in philosophy of science, see: Hedström and Ylikoski (2010: 61-2).
} 
normative considerations and problems, and new tools for normative analysis (see also: Longo and Zacka 2019).

The distinction between theory-building and theory-application is not an impermeable bright line in any branch of human inquiry. It is therefore unsurprising that realism's intellectual terrain - in this methodological framing - overlaps with some existing forms of (moralist) political theory. This may frustrate some realists, but it should be an unradical implication. As Sleat (2018: 8) suggests: "one thing that unites realistic theories...is the sense that the reality of politics ought to play some significant role in directing the theorist's activity." Such a sentiment is obviously not unique to realists, being also a feature of, at least, non-ideal theory (O'Neill 1997; Simmons 2010; Valentini 2012; Stemplowska and Swift 2012), critical theory (Shelby 2003; McNay 2013) and recent ethnographically informed approaches to political theory (Longo and Zacka 2019; Zacka et al. 2020). So the line between realists and non-realists is already fuzzy, and we should embrace an image of political theory methods as spanning a variegated spectrum of more or less 'realist' and 'idealist' (the correct contrast, in this framing) approaches, rather than falling into two mutually exclusive camps.

But this does not imply that realism is merely a subset of existing 'non-ideal theory'. As presently understood, non-ideal theory is largely defined by concerns with partial compliance, feasibility constraints and practice dependence (Stemplowska 2008; Stemplowska and Swift 2012; Valentini 2012). These could also be realist concerns. But realists can diverge from nonideal theorists in two main ways. First, realists may contend that the narrow focus on these three issues is arbitrary: a vast range of further empirically constitutive political realities need theorisation, leaving most of the spectrum open for realists to explore. Second, realists are likely to think that non-ideal theorists do not go far enough in grappling with the constitutive political realities that underlie partial compliance, feasibility and practice dependence specifically - still largely 'plugging them in' to pre-existing moral theories. A realist approach could go deeper: treating partial compliance, for example, not as an abstract generic obstacle to ideal theory, but as rooted in multiple real-world sources of compliance and non-compliance (domination and resistance versus cultural integration and divergence, for example) that carry distinct normative implications.

This framing leaves room for much methodological debate between different positions on the idealist-realist spectrum. But it should also clarify that no singular point on the spectrum is 'correct'. Normative questions can, and should, be posed at different levels of contingency: asking what we should do under different assumptions about which features of 'reality' are fixed and not fixed. How important it is for a particular political theory to attend effectively to empirically constitutive political realities thus depends on the specific normative questions it is asking, and its broader aims and functions within the overall division of academic labour (see also: Blau 2017; Frazer 2016). Idealist methods, such as thought-experiments, rational choice analysis or reflective equilibrium, may neglect constitutive political realities while still serving other important theoretical functions. Moreover, different realist theories will handle different constitutive political realities to varying degrees of effectiveness and towards different ends. This framing of realism thus encourages a pluralist vision of political theory methods. Political theories may be defective in various ways, so methodological debates are best construed as efforts to clarify what exactly a method is and is not useful for, rather than as contests between mutually exclusive 'rival' approaches.

Realists have sometimes not helped matters here by mischaracterising non-realist forms of theorisation. Realists have, for example, wrongly implied that 'ideal theory' seeks to provide empirical understandings of politics (Geuss 2008: 39 \& 90; Newey 2001: 2), or directly dictate 
real political outcomes and guide political actors (Geuss 2008: 7-10; Philp 2010: 469; Horton 2010: 436; Miller 2013: 2-4). They have also implied that moralists fail to recognise that "values [alone] underdetermine which action should be chosen" (Philp 2010: 474) or that "[o]rder cannot be provided by philosophical arguments alone" (Jubb 2016: 97). This really is caricature. Political theorists have repeatedly emphasised that idealist approaches are not intended to directly prescribe solutions in real politics - a leading text on ideal theory states, for example, that "[r]eflection on ideal or proper justice on its own cannot tell us which actions, policies, and institutions to adopt" (Stemplowska 2008: 338). Idealisation is not some kind of attempt to wish away inconvenient realities but a methodological strategy that serves (at least) three main purposes. First, idealist methods help isolate and assess the underlying values, meanings, assumptions and coherence of arguments, by distilling the core reasoning those arguments express (List and Valentini 2016; Brownlee and Stemplowska 2017). Second, idealist methods help theorise right action irrespective of the extent of non-compliance, on the intuitive premise that wrongdoing does not cease being wrong just because it is widespread (Valentini 2012; Estlund 2017: 386). Third, idealist methods help challenge status-quo bias in normative theory and expand our normative horizons, in recognition of the fact that human beings cannot be confident which features of reality are genuinely unchangeable (McKean 2016).

So while idealist methods involve some disconnection from constitutive political realities, they nevertheless help avoid certain important kinds of theoretical error in our normative thinking about politics (see also: O'Neill 1997: 419-21). They have not failed to grasp the 'true' purpose of political theory, and are not flawed for failing to answer questions they do not attempt to address. Yet I side with realists in thinking that much contemporary political theory relies excessively on idealist methods - arbitrarily prioritising the avoidance of certain kinds of error (surrounding the precision and logical coherence of normative argumentation) over others (such as a bias against considerations distinctive to real political situations, a disregard of political theories' ideological effects, and so on). This methodological framing does not, therefore, drain realism of its critical force. Significant debate will remain over how much realism (and idealism) we need, how realist and idealist contributions interrelate, and the comparative value of different theoretical methods in response to different puzzles and contexts. But this should be the heart of methodological debates in political theory. Efforts to orientate political realism around the still inchoate notion of a distinctively political normativity, by contrast, should be recognised as a blind alley - a path avoided by realism's intellectual progenitors, and which seems more rooted in rhetorical rallying cries than compelling methodological problems.

\section{Conclusion}

The most enduring concern of realist thinkers has been with the shortcomings and dangers of certain forms of moral theorising that are too detached from, idealistic about, or antagonistic to real politics. Such concerns require no metaethical notion of a distinctive political normativity - a notion which takes realism into theoretical controversies for which most of its protagonists display little interest, and which often suggests a misunderstanding of the way 'moralists' actually conceptualise morality and moral normativity. What we need, instead, is a deeper form of methodological reflection on the way we build and apply political theories, and on those characteristic features of particular political situations which should systematically influence at least some of the ways in which we think normatively about politics. 
Orientating realism around such 'empirically constitutive political realities' has several advantages. It encourages a more pluralist understanding of political theory methods, in which realists and their opponents are not engaged in wholly alien activities involving totally different kinds of normativity, but are employing different strategies, with different strengths and weaknesses, to address distinct but overlapping normative questions. It pushes realism away from abstract and often rather essentialist arguments about the concept or general character of 'the political' in favour of richer, empirically grounded forms of innovative theory about critical features of actual political contexts. It also highlights important connections, in this respect, between realism and other forms of political theory that do not resemble the 'applied morality' model.

I do not present this framing as a radically 'new' form of realism, and have emphasised its compatibility with much existing realist work. It captures, I contend, the strongest motivational impulses behind both recent realist political theory and earlier 'proto-realist' writings. But figures like Morgenthau, Weber, Arendt, Berlin or Shklar were right, in my view, to focus their critical attention on the dangers of specific sorts of moral theorising which failed to take seriously various enduring realities of our political life. They recognised that moral judgements still underpinned their work, but nevertheless made the theorisation of such enduring political realities foundational to their thinking about politics. That remains a more urgent, nuanced, and convincing project for realism than any sweeping hostility to moral normativity as such.

Acknowledgements My thanks to Carlo Burelli, Illaria Cozzaglio, Chiara Destri, Eva Erman, Favara Greta, Matthew Longo, Enzo Rossi, Cord Schmelzle, Matt Sleat, Manon Westphal, Alex Worsnip and all participants of the 'Political Normativity: Realism Meets Critics' workshop at the University of Milan (10/10/2019) and the 'Realism and Moralism in International Politics' panel at the ECPR General Conference (held online 25/08/2020) for their invaluable feedback on earlier versions of this paper.

Open Access This article is licensed under a Creative Commons Attribution 4.0 International License, which permits use, sharing, adaptation, distribution and reproduction in any medium or format, as long as you give appropriate credit to the original author(s) and the source, provide a link to the Creative Commons licence, and indicate if changes were made. The images or other third party material in this article are included in the article's Creative Commons licence, unless indicated otherwise in a credit line to the material. If material is not included in the article's Creative Commons licence and your intended use is not permitted by statutory regulation or exceeds the permitted use, you will need to obtain permission directly from the copyright holder. To view a copy of this licence, visit http://creativecommons.org/licenses/by/4.0/.

\section{References}

Anderson E (2010) The imperative of integration. Princeton, Princeton University Press

Blau A (ed) (2017) Methods in analytical political theory. Cambridge, Cambridge University Press

Broome J (1999) Normative Requirements. Ratio 12:398-419

Broome J (2013) Rationality through reasoning. Wiley Blackwell, Malden

Brownlee K, Stemplowska Z (2017) Thought experiments. In: Blau A (ed) Methods in analytical political theory. Cambridge University Press, Cambridge

Dorsey D (2016) Moral distinctiveness and moral inquiry. Ethics 126:747-773

Erman E, Möller N (2015) Political legitimacy in the real normative world: the priority of morality and the autonomy of the political. Br J Polit Sci 45:215-233

Estlund D (2014) Utopophobia. Philos Public Aff 42:113-114

Estlund D (2017) Methodological moralism in political philosophy. Crit Rev Int Soc Pol Phil 20:385-402

Forrester K (2012) Judith Shklar, Bernard Williams and political realism. Eur J Polit Theo 11:247-272

Frazer E (2018) Feminism and realism. In: Sleat M (ed) Politics recovered: realist thought in theory and practice. Columbia University Press, New York 
Frazer ML (2016) Utopophobia as a vocation: the professional ethics of ideal and nonideal political theory. Soc Philos Policy 33:175-192

Gert B, Gert J (2016) The definition of morality. Philosophy, Stanford Encyclopedia of

Geuss R (2008) Philosophy and real politics. Princeton, Princeton University Press

Hall E (2013) Political realism and fact-sensitivity. Res Publica 19:173-181

Hall E (2015) Bernard Williams and the basic legitimation demand: a Defence. Pol Stud 63:466-480

Hall E (2017) How to do realistic political theory (and why you might want to). Eur J Polit Theo 16:283-303

Hare RM (1981) Moral thinking: its levels, method, and point. Oxford, Oxford University Press

Hedström P, Ylikoski P (2010) Causal Mechansims in the social sciences. Annu Rev Sociol 36:49-67

Horton J (2010) Realism, Liberal moralism and a political theory of modus vivendi. Eur J Polit Theo 9:431-448

Jubb R (2009) Logical epistemic foundationalism about grounding: the triviality of facts and principles. Res Publica 15:337-353

Jubb R (2015) Playing Kant at the court of king Arthur. Pol Stud 63:919-934

Jubb R (2016) Recover it from the facts as we know Them': practice-dependence's predecessors. J Moral Philos 13:77-99

Jubb R (2017) Realism. In: Blau A (ed) Methods in analytical political theory. Cambridge University Press, Cambridge

Jubb R (2019) 'On what a distinctively political normativity is’, Political Studies Review, OnlineFirst Version, pp 360-369

Korsgaard C (1996) The sources of normativity. Cambridge, Cambridge University Press

Kymlicka W (1989) Liberal individualism and Liberal neutrality. Ethics 99:883-905

Larmore C (2018) The truth in political realism. In: Sleat M (ed) Politics recovered: realist thought in theory and practice. Columbia University Press, New York

Leader Maynard J, Worsnip A (2018) Is there a distinctively political normativity? Ethics 128:756-787

List C, Valentini L (2016) The methodology of political theory. In: Cappelen H, Szabó T, Hawthorne J (eds) The Oxford handbook of philosophical methodology. Oxford University Press, Oxford

Longo, Matthew, and Bernardo Zacka. 2019. 'Political theory in an ethnographic key', American Political Science Review, OnlineFirst Version.

Mantena K (2012) Another realism: the politics of Gadhian nonviolence. Am Pol Sci Rev 106:455-470

McKean BL (2016) What makes a utopia inconvenient? On the advantages and disadvantages of a realist orientation to politics. Am Pol Sci Rev 110:1-13

McNay L (2013) Contemporary Critical Theory. In: Freeden M, Sargent LT, Stears M (eds) The Oxford Handbook of Political Ideologies. Oxford, Oxford University Press

Miller D (2008) Political philosophy for earthlings. In: Leopold D, Stears M (eds) Political theory: methods and approaches. Oxford University Press, Oxford

Miller D (2013) Justice for earthlings. Cambridge, Cambridge University Press

Morgenthau HJ (1948/1993) Politics Among Nations: The Struggle for Power and Peace - Brief Edition. McGraw Hill, Boston

Nagel T (1987) Moral conflict and political legitimacy. Philos Public Aff 16:215-240

Newey G (2001) After politics: the rejection of politics in contemporary Liberal philosophy. Palgrave Macmillan, Houndmills

Nye S (2015) Real politics and Metaethical baggage. Ethical Theory Moral Pract 18:1083-1100

O'Neill O (1997) Philosophical liberalism and public reason: a critical notice of John Rawls, Political Liberalism. Philos Rev 106:411-428

Owen D (2018) Realism in ethics and politics: Bernard Williams, political theory, and the critique of morality. In: Sleat M (ed) Politics recovered: realist thought in theory and practice. Columbia University Press, New York

Pettit P (2017) Political realism meets civil republicanism. Crit Rev Int Soc Pol Phil 20:331-347

Philp M (2010) What is to be done? Political theory and political realism. Eur J Polit Theo 9:466-484

Philp M (2012) Realism without illusions. Political Theory 40:629-649

Prinz J, Rossi E (2017) Political realism as ideology critique. Crit Rev Int Soc Pol Phil 20:348-365

Rawls J (1993) Political liberalism. Columbia University Press, New York

Rossi E, Sleat M (2014) Realism in normative political theory. Philos Compass 9:689-701

Sabl A, Sagar R (2017) Introduction. Crit Rev Int Soc Pol Phil 20:269-277

Sagar P (2018) Legitimacy and domination. In: Sleat M (ed) Politics recovered: realist thought in theory and practice. Columbia University Press, New York

Shelby T (2003) Ideology, racism, and critical social theory. Philos Forum 34:153-188

Shklar JN (1989) The Liberalism of Fear. In: Rosenblum NL (ed) Liberalism and the Moral Life. Harvard University Press, Cambridge

Simmons AJ (2010) Ideal and nonideal theory. Philos Public Aff 38:5-36

Sleat M (2016) What is a political value? Political philosophy and Fidelity to reality. Soc Philos Policy 33:252-272

Sleat M (2018) Introduction: politics recovered - on the revival of realism in contemporary political theory. In: Sleat M (ed) Politics recovered: realist thought in theory and practice. Columbia University Press, New York 
Stemplowska Z (2008) What's ideal about ideal theory? Soc Theory Pract 34:319-340

Stemplowska Z, Swift A (2012) Ideal and nonideal theory. In: Estlund D (ed) The Oxford handbook of political philosophy. Oxford University Press, Oxford

Valentini L (2012) Ideal vs. non-ideal theory: a conceptual map. Philos Compass 7:654-664

Walker RBJ (1992) Inside/outside: international relations as political theory. Cambridge, Cambridge University Press

Walzer M (1980) The moral standing of states: a response to four critics. Philos Public Aff 9:209-229

Williams B (1985) Ethics and the limits of philosophy. London, Fontana Press

Williams B (2005) In the beginning was the deed: realism and moralism in political argument. Princeton, Princeton University Press

Ylikoski P (2013) Causal and constitutive explanation compared. Erkenntnis 78:277-297

Zacka B, Ackerly B, Elster J, Allen SG, Iqtidar H, Longo M, Sagar P (2020) 'Political theory with an ethnographic sensibility', Contemporary Political Theory, OnlineFirst Version, pp 1-34

Publisher's Note Springer Nature remains neutral with regard to jurisdictional claims in published maps and institutional affiliations. 